\title{
Morphogenetic characterization of Colletotrichum sublineolum strains, causal agent of anthracnose of Sorghum
}

\author{
Gabriela F. Zanette, Gisele M.A. Nóbrega \& Luzia D.P. Meirelles \\ Departamento de Biologia Geral, Universidade Estadual de Londrina, 86051-990, Londrina, PR, Brazil
}

Author for correspondence: Luzia D.P. Meirelles, e-mail: paccola@uel.br

\begin{abstract}
Anthracnose, caused by Colletotrichum sublineolum, has been one of the most destructive diseases affecting sorghum crops in Brazil. This study aimed to characterize wild and mutant strains through morphological and cultural characteristics, conidiation, and mating-type. A high variability was observed among strains when evaluated through radial growth and type of conidia produced. Spontaneous release of sectors by some strains was also observed, confirming the high genetic instability of this pathogen. Mating type genes amplified through PCRs using the primers, SKCM1, NcHMG and HGMgram demonstrated that both idiomorphs are present in this species. All the strains analyzed were self-sterile. It was not possible to correlate the auxotrophic mutant phenotype with the morphological characteristics evaluated.
\end{abstract}

Keywords: conidial dimorphism, sexual cycle, mating type.

\section{RESUMO}

Caracterização morfogenética de linhagens de Colletotrichum sublineolum, agente causal da antracnose do sorgo

A antracnose, causada por Colletotrichum sublineolum tem sido uma das mais destrutivas doenças que afetam a cultura do sorgo no Brasil. Este estudo teve como objetivo caracterizar linhagens selvagens e mutantes em relação à morfologia, produção de conídios e mating type. Uma alta variabilidade entre as linhagens foi observada em relação ao crescimento radial e produção de conídios ovais e falcados. Setores foram liberados espontaneamente por algumas linhagens, o que confirma a alta instabilidade genética deste patógeno. Genes ligados a característica mating type foram amplificados por PCRs utilizando os primers SKCM1, NcHMG e HGMgram, demonstrando que ambos os idiomorfos estão presentes nesta espécie. Todas as linhagens estudadas foram auto-estéreis. Não foi possível detectar correlação entre o fenótipo auxotrófico mutante e as características morfológicas avaliadas.

Palavras-chave: dimorfismo conidial, ciclo sexual, mating type.

\section{INTRODUCTION}

Anthracnose caused by Colletotrichum sublineolum P. Henn. is one of the most destructive diseases of sorghum (Sorghum bicolor L. Moench), especially in warm and humid areas of the world (Harris \& Johnson, 1967; Ali \& Warren, 1992). The disease is present in all of the major sorghum growing areas of Brazil where it causes severe losses in yield and quality of grain, depending on the susceptibility of the cultivar and the severity of the epidemics (Guimarães et al., 1999). Losses exceeding $50 \%$ on production of grains have been reported, especially when there is alternation of dry and humid conditions combined with high temperatures (Casela et al., 1997). In nature, the fungus occurs in the mitosporic form and can survive as mycelium, conidia and/or sclerotia in crop debris and infected seed (Casela \& Ferreira, 1998). Genetic resistance has been the main strategy for the control of this disease, but host-specific resistance is often unstable because of the high variability in the pathogen population (Ali \& Warren, 1987; Casela \& Ferreira, 1995; Bressan \& Figueiredo, 2003).
The mechanisms of genetic material transfer used by $C$. sublineolum are still little known. Despite the fact that it can be easily cultivated under a variety of conditions, an advantage that makes it an appropriate organism for physiological and biochemical studies, fewer genetic studies have been reported in this species (Souza-Paccola et al., 2003b). In many fungi, sexual reproduction is controlled by mating-type genes (MAT genes) with two alternative forms MAT1 and MAT2 called idiomorphs (Coppin et al., 1997; Turgeon, 1998). Mating type genes regulate sexual compatibility and sexual reproduction in fungi. Molecular analysis of the nucleotide sequences of MAT gene suggest that all encode transcriptional regulators; one of the pair of MATgenes encodes a protein with a conserved DNA binding motif called the high mobility group (HMG) box (Arie et al., 1997) (Figure 1). The other MAT idiomorph encodes a protein that has a region called alpha box (Turgeon, 1998).

In the ascomycete Glomerella graminicola, teleomorph of $C$. graminicola, the cross system is complex and is governed by two loci (Vaillancourt et al., 2000). One of the loci is not a typical MAT idiomorph of ascomycetes 


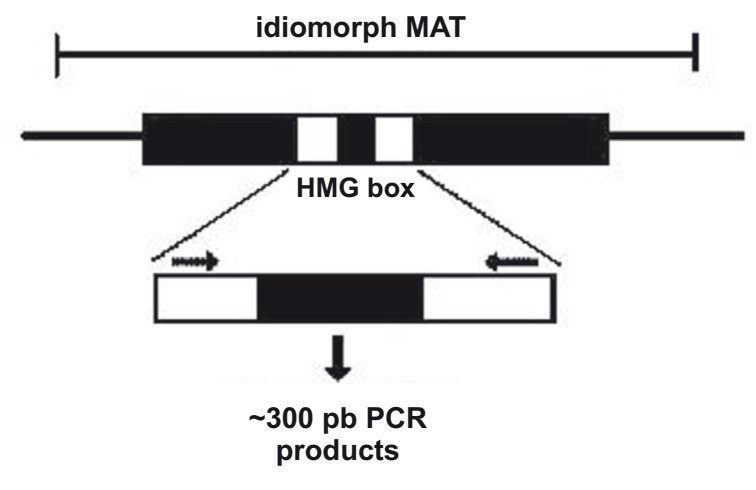

FIGURE 1 - Scheme of MAT gene structure and the amplification of the conserved region. The white region is used as model to design primers, and in the center the black region that is amplified at PCR. The arrows show the directions of amplifications initiated by the primers. (based on Arie et al., 1997).

because the $H M G$ box region of the MAT2 idiomorph on $G$. graminicola was found in both parents of a cross, but the alpha box sequence of MAT1 was not amplified. If G.graminicola has a MAT 1 gene similar to the other ascomycetes it may be that it does not contain a well preserved alpha box sequence (Du et al., 2005). Understanding mating type systems could help in elucidating the mechanisms of sexual dimorphism and should help to improve genetic analysis. The purpose of this study was to characterize strains of $C$. sublineolum through morphological and cultural variability, and the presence of mating-type genes.

\section{MATERIALS AND METHODS}

\section{Strains of $C$. sublineolum}

Wild monosporic strains were obtained from the Plant Pathology Laboratory of the Maize and Sorghum Research Center, located in Sete Lagoas/MG-BR, and mutant strains were obtained by Fávaro et al. (2007) and belong to the culture collection of the Fungal Genetics Laboratory of the State University of Londrina, PR (Table 1).

\section{Cultural characteristics and production of falcate and oval conidia}

Mycelium discs of $10 \mathrm{~mm}$ diameter were placed in oatmeal agar plates and incubated at $28^{\circ} \mathrm{C}$ under continuous fluorescent light; colony growth was evaluated at an interval of 24 hours, until it reached the edge of the plate. For each strain the growth of three culture plates was measured. The evaluation of falcate and oval conidia production followed the methodology described by Souza-Paccola et al. (2003a). Falcate conidia were produced by transferring strains to oatmeal Agar plates (three plates for each strain) which were incubated under continuous fluorescent light at $28^{\circ} \mathrm{C}$ for 7 days. After this period the colonies were injured with a Drigalski handle and incubated for 7 days more under the above described conditions. After incubation, falcate conidia were collected in $0.01 \%$ Tween 80 in water and diluted with saline solution. The number of falcate conidia was estimated in a Neubauer-counting chamber, with three evaluations for each repetition. A completely randomized design was used and the experiments were conducted in duplicate. Oval conidia were produced in Potato Dextrose Broth (PDB). Three mycelial discs, each $10 \mathrm{~mm}$ in diameter, were used to inoculate $50 \mathrm{~mL}$ of PDB (three repetitions for each strain tested), and the cultures were kept under agitation at room temperature for 7 days. The mycelia were filtered through sterile cheesecloth and oval conidia were recovered by centrifugation at $6000 \mathrm{~g}$ for $5 \mathrm{~min}$. The pellet was resuspended in $2 \mathrm{~mL}$ of sterile aqueous solution of $0.01 \%$ Tween 80 . The number of falcate conidia and oval conidia was estimated in a Neubauer-counting chamber, with three evaluations for each repetition. The mean size of 30 oval conidia, of each treatment, was estimated using a micrometric ocular. A completely randomized design was used and the experiments were conducted in duplicate.

\section{Extraction of DNA}

The strains were grown in PDB for seven days under agitation (90rpm) at $25^{\circ} \mathrm{C}$. For total DNA extraction, $500 \mathrm{mg}$

TABLE 1 - C. sublineolum strains used in this work

\begin{tabular}{lll}
\hline \hline Strain & Phenotype* & \multicolumn{1}{c}{ Origin } \\
\hline 30C & Wild & Embrapa - Sete Lagoas \\
85.02 & Wild & Embrapa - Sete Lagoas \\
Embrapa - Sete Lagoas & Wild & \\
& & \\
15A.109 & Nit M Mutant & Fávaro et al., 2007 \\
15A.124 & Nit M Mutant & Fávaro et al., 2007 \\
15A.162 & Nit M Mutant & Fávaro et al., 2007 \\
15B.04 & Nit M Mutant & Fávaro et al., 2007 \\
15B.11 & Nit M Mutant & Fávaro et al., 2007 \\
15B.15 & Nit M Mutant & Fávaro et al., 2007 \\
15B.20 & Nit M Mutant & Fávaro et al., 2007 \\
15B.23 & Nit M Mutant & Fávaro et al., 2007 \\
15E.12 & Nit M Mutant & Fávaro et al., 2007 \\
15E.12.1 & Nit M Mutant & Fávaro et al., 2007 \\
15E.22.2 & Nit M Mutant & Fávaro et al., 2007 \\
30C.17 & Nit M Mutant & Fávaro et al., 2007 \\
30C.41 & Nit M Mutant & Fávaro et al., 2007 \\
30C.67 & Nit M Mutant & Fávaro et al., 2007 \\
30C.74 & Nit M Mutant & Fávaro et al., 2007 \\
& & \\
15E.11 & nit1 Mutant & Fávaro et al., 2007 \\
15E.15 & nit1 Mutant & Fávaro et al., 2007 \\
30C.12 & nit1 Mutant & Fávaro et al., 2007 \\
30C.122 & nit1 Mutant & Fávaro et al., 2007 \\
30C.151 & nit1 Mutant & Fávaro et al., 2007 \\
\hline Mution & & \\
\hline nestrat &
\end{tabular}

*nit $1=$ Mutation in the structural locus of nitrate reductase gene. nit $\mathrm{M}=$ mutation in the loci responsible by production of a co-factor containing molybdenum, required for the activity of nitrate reductase enzymes and purine dehydrogenase. 
of mycelia of each isolate was ground to a powder in liquid nitrogen and extracted in $800 \mu \mathrm{L}$ of extraction buffer $(100 \mathrm{mM}$ TRis - $\mathrm{HCl}$ (pH 8.0), 25mM EDTA, $1 \%$ SDS, $25 \mathrm{mM} \mathrm{NaCl}$ ) following an incubation period of 20 minutes at $65^{\circ} \mathrm{C}$. After the incubation period, $800 \mu \mathrm{L}$ of phenol was then added to the samples and centrifuged for 20 minutes at $12,000 \mathrm{~g}$. The supernatant was collected and transferred to centrifuge tubes, followed by addition of phenol and chloroform $(1 \mathrm{~mL}$ each). After centrifugation for 15 minutes at $12,000 \mathrm{~g}$, equal volume of chlorophyll (24 chloroform: 1 alcohol isoamilic $\mathrm{v} / \mathrm{v}$ ) was added to the supernatant and again centrifuged for $15 \mathrm{~min}$. Ice-cold ethanol absolute ( 2 volumes) and 1/10 the amount of $\mathrm{NaCl} 3 \mathrm{M}$ was added to the supernatant, which was incubated for one hour at $-18^{\circ} \mathrm{C}$ and centrifuged for 5 minutes at $12,000 \mathrm{~g}$. To the precipitate, $300 \mu \mathrm{L}$ of ethanol $70 \%$ was added, following centrifugation for $5 \mathrm{~min}$ at $12,000 \mathrm{~g}$. The supernatant was discarded and after drying the DNA at room temperature it was resuspended in $100 \mu \mathrm{L}$ of distilled water. The DNA concentration was estimated by comparison with DNA standards on $0.7 \%$ agarose gel electrophoresis. The extracted DNA was maintained at $4^{\circ} \mathrm{C}$.

\section{Polymerase Chain Reactions (PCR)}

The degenerated primers SkCM 1 and $\mathrm{NcHMG}$ and the specific primer HMGgram were used to perform PCR reactions aiming to identify the presence of idiomorph mating-type genes and characterize the strains of $C$. sublineolum in their mating-type. All reactions were prepared according to Arie et al. (1997) with some modifications. The reactions were performed in a final volume of $25 \mu \mathrm{L}$ containing: 20ng of DNA, $2.5 \mathrm{mM}$ of $\mathrm{MgCl}^{2}, 0.25 \mathrm{mM}$ of dNTP, $2.0 \mathrm{mM}$ of each primer and 1U of Taq DNA polymerase (Invitrogen, Brazil); $10 \mathrm{mM}$ of buffer Tris- $\mathrm{HCl}$ $\mathrm{pH} 8.3$ and $50 \mathrm{mM}$ of $\mathrm{KCl}$. Reactions of primers NcHMG (5 'CG CC (CT) (CT) CC (CT) CC (CT) AA (CT) GCTA (CT) AT 3' and 5 'CGGG (AG) TT (AG) TA (AG) CG (AG) TA (GA) T (AG) GG 3 '), were held with the annealing temperature at $50^{\circ} \mathrm{C}$ for 1 minute. For amplifications of SkCM1 primers (5 'GCAGATCTCCGCACTGGAGC 3' and 5 'GCAGATCTGTCGTCGATGGT 3') (Wirsel et al., 1996) the conditions of annealing were: $60^{\circ} \mathrm{C}$ for $1 \mathrm{~min}$. For HMGgram primers (5 'CGTATATTCTCTACCGCAAGG 3' and 5' GGGGGTGCAGTTTGTTATG 3') (Du et al., 2005) amplifications were held at $55^{\circ} \mathrm{C}$ of annealing temperature for 50 seconds. All reactions were performed in thermocycler PTC-100 (MJ Research, Inc.). For analysis of PCRs products, $15 \mu \mathrm{L}$ of each reaction was subjected to electrophoreses on $1.3 \%$ agarose gel.

\section{RESULTS}

\section{Cultural characteristics and falcate and oval conidia production}

Based on morphological variation, six different types of colonies were formed. The colony color ranged from white to pink and dark-gray to clear-gray. The strains 15B.04, 15B.15 and 30C. 41 formed sectors during vegetative growth, showing a high genetic instability of this pathogen, as described by Fávaro et al. (2007). The mycelial growth differed among strains. The 15B.04 strain showed a greater growth rate, while the strain 30C.151 presented the slowest growth rate (Table 2). Both mutants and wild type produced at least one of the two types of conidia normally found in the species. The falcate conidia were observed only in solid culture media, with the concentration ranging from 0 , in strains $15 B .04,15 \mathrm{E} .22 .2$ and $15 \mathrm{E}$, to $190.8 \times 10^{5}$ conidia $/ \mathrm{mL}$ in strain 204.01 (Table 2). Mutant strains 15B.23 and 15E.11 were able to produce falcate conidia spontaneously, whereas the other mutants produced this kind of conidium only after a mechanical shock in the mycelium (colonies were injured with a Drigalski handle). Morphological variations were not observed among falcate conidia, demonstrating that the morphology of this asexual structure was not altered by the mutation. The falcate conidia were hyaline, unicellular, non-septate, with rounded ends. A high variation in the ability to produce oval conidia was observed among strains, ranging from 0 in the strains $30 \mathrm{C} .41$ and $30 \mathrm{C} .67$ to 16.7 $\mathrm{x} 10^{5}$ conidia $/ \mathrm{mL}$ in the strain $30 \mathrm{C} .151$. Similar to falcate conidia, the mutation also did not affect the morphology of oval conidia, which varied in the size and shape. All of them were hyaline and smaller than the falcate ones (Table 2).

\section{Identification of mating-type genes in $C$. sublineolum}

The nomenclature used in this study followed as proposed by Turgeon and Yoder (2000), where MAT1 comes to MAT gene that has stayed in the region alpha box and MAT2 to the gene MAT that has the region $H M G$ box. When the degenerated primer NcHMG was used, only 8 of the tested strains, among them 3 wild and 5 mutants, amplified for MAT2 gene. A 400bp fragment was obtained (Figure 2), which is in agreement with Arie et al. (1997). But when the specific primer HMGgram for C. graminicola (Du et al., 2005) was used, 16 strains amplified for MAT2 gene (Figure 3), with a $\sim 300 \mathrm{pb}$ fragment, indicating that the use of specific primers is needed for better efficiency on amplification. Only the strains 15A, 15B.04, 15E.12, 15E.22.2 and 30C.38 amplified for primer HMGgram and SkCM (MAT1) (Figures 3-4), indicating that these strains have the two idiomorph for the mating-type gene, MAT1 and MAT2. A lack of amplification for both idiomorphs was verified in strains 15A.109, 15A.124, 15B.46, 30C.05, 30C.12, 30C.17, 30C.67, 30C.70. Only one strain, the 15B.11, amplified for primer NcHMG but did not for the primer HMGgram.

\section{DISCUSSION}

\section{Cultural characteristics}

Both wild and mutant strains of $C$. sublineolum presented a high cultural variability, and all of them produced at least one of two types of conidia described in 
Morphogenetic characterization of Colletotrichum sublineolum strains..

TABLE 2 - C. sublineolum cultural characteristics: vegetative growth and falcate and oval conidia production

\begin{tabular}{|c|c|c|c|c|c|}
\hline Strain* & $\begin{array}{l}\text { Colony } \\
\text { color }\end{array}$ & $\begin{array}{c}\text { Mycelial growth } \\
(\mathrm{cm}) \\
\text { (mean of } 3 \\
\text { repetition) }\end{array}$ & $\begin{aligned} \text { Coni } \\
\text { (mear }\end{aligned}$ & $\begin{array}{l}\text { duction } \\
\text { petition) }\end{array}$ & $\begin{array}{l}\text { Oval conidia } \\
\text { average size }(\mu \mathrm{m})\end{array}$ \\
\hline \multirow[b]{2}{*}{ Wild } & \multirow[b]{3}{*}{ Green-gray } & \multirow[b]{3}{*}{$7.0 \mathrm{a}$} & $\begin{array}{c}\text { Falcate } \\
\left(\mathrm{n} \times 10^{5} \text { conidia/mL) }\right.\end{array}$ & \multicolumn{2}{|c|}{$\begin{array}{c}\text { Oval } \\
\left(\mathrm{n} \times 10^{5} \text { conidia } / \mathrm{mL}\right)\end{array}$} \\
\hline & & & & & \\
\hline 204.01 & & & $190.80 \mathrm{a}$ & $1.72 \mathrm{de}$ & $14 \times 5 \mathrm{c}$ \\
\hline 85.02 & Clear-gray & $6.7 \mathrm{a}$ & $1.70 \quad \mathrm{~d}$ & $2.33 \mathrm{cde}$ & $17 \times 4 b$ \\
\hline \multicolumn{6}{|c|}{ nitM Mutant } \\
\hline 15A.109 & $\begin{array}{l}\text { Medium- } \\
\text { gray }\end{array}$ & $7.1 \mathrm{a}$ & 0.01 & 0.30 & $13 \times 4 d$ \\
\hline 15B.04 & White & $8.0 \mathrm{a}$ & No production & $3.66 \mathrm{cde}$ & $13 \times 4 d$ \\
\hline 15B.15 & Green-gray & $7.6 \mathrm{a}$ & 0.02 & $2.46 \mathrm{cde}$ & $17 \times 5 b$ \\
\hline 15B.23 & Green-gray & $6.9 \mathrm{a}$ & $6.27 \quad \mathrm{c}$ & $4.40 \mathrm{~cd}$ & $17 \times 5 b$ \\
\hline 15E.12.1 & $\begin{array}{l}\text { Medium- } \\
\text { gray }\end{array}$ & $5.6 \mathrm{e}$ & $3.00 \mathrm{de}$ & $5.05 \mathrm{~cd}$ & $14 \times 3 \mathrm{~cd}$ \\
\hline 15E.22.2 & Green-gray & $5.0 \mathrm{f}$ & No production & $6.04 \mathrm{bc}$ & $15 \times 3 c$ \\
\hline 30C.17 & Green-gray & $6.8 \mathrm{a}$ & $9.34 \quad \mathrm{c}$ & 0.91 & $13 \times 4 d$ \\
\hline $30 \mathrm{C} .41$ & Cinza claro & $6.4 \mathrm{bc}$ & 0.03 & No production & \\
\hline 30C.67 & Green-gray & $4.7 \quad \mathrm{fg}$ & 0.56 & No production & \\
\hline 30C.74 & Green-gray & $6.1 \mathrm{de}$ & 0.02 & $0.29 \quad \mathrm{e}$ & $15 \times 4 c$ \\
\hline \multicolumn{6}{|c|}{ nit1 Mutant } \\
\hline 15E. 11 & Dark-gray & $6.6 \mathrm{ab}$ & $38.54 \mathrm{~b}$ & 0.93 & $18 \times 4 a b$ \\
\hline 15E. 15 & Clear-gray & $5.6 \mathrm{e}$ & No production & $11.61 \mathrm{ab}$ & $17 \times 3 b$ \\
\hline 30C.151 & Pink & 4.4 & 0.01 & $16.70 \mathrm{a}$ & $9 \times 2$ \\
\hline
\end{tabular}

*nit $1=$ Structural change in the locus of nitrate reductase. nitM= mutation in one of the loci responsible for the production of a co-factor containing molybdenum required for the activity of nitrate reductase enzymes and purine dehydrogenase. Means in the same column followed by the same letter do not differ significantly by Tukey Test $(\mathrm{p} \leq 0.05)$.

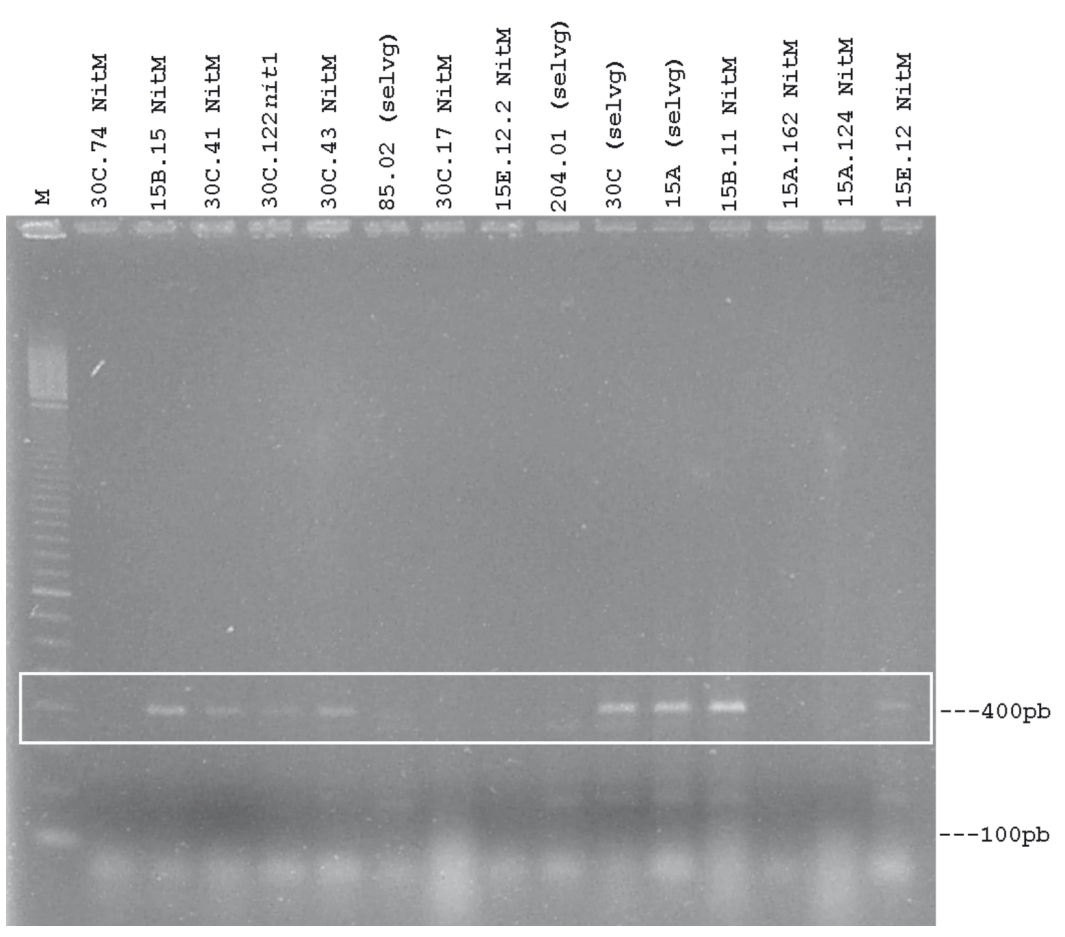

FIGURE 2 - PCR products obtained with primer NcHMG (MAT2) on $1.4 \%$ agarose gel. 


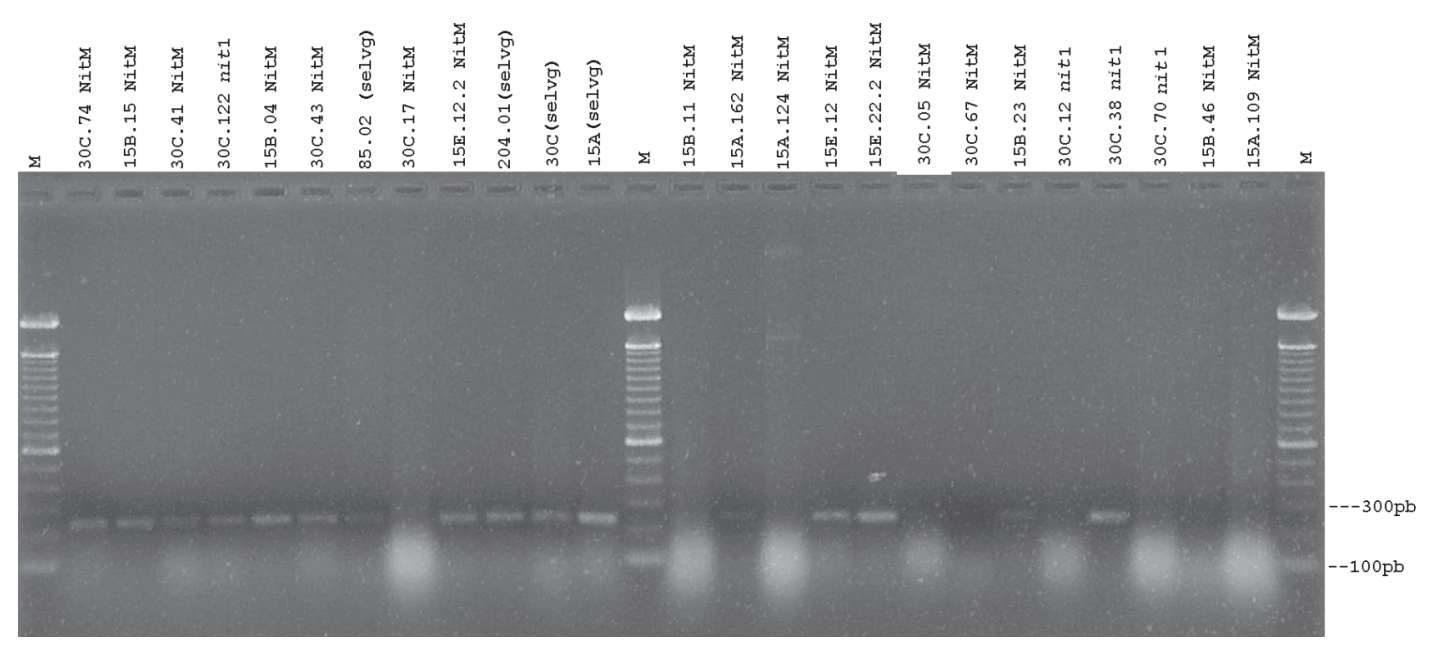

FIGURE 3 - PCR products obtained by amplification with primer HMGgram (MAT2) on 1.4\% agarose gel.

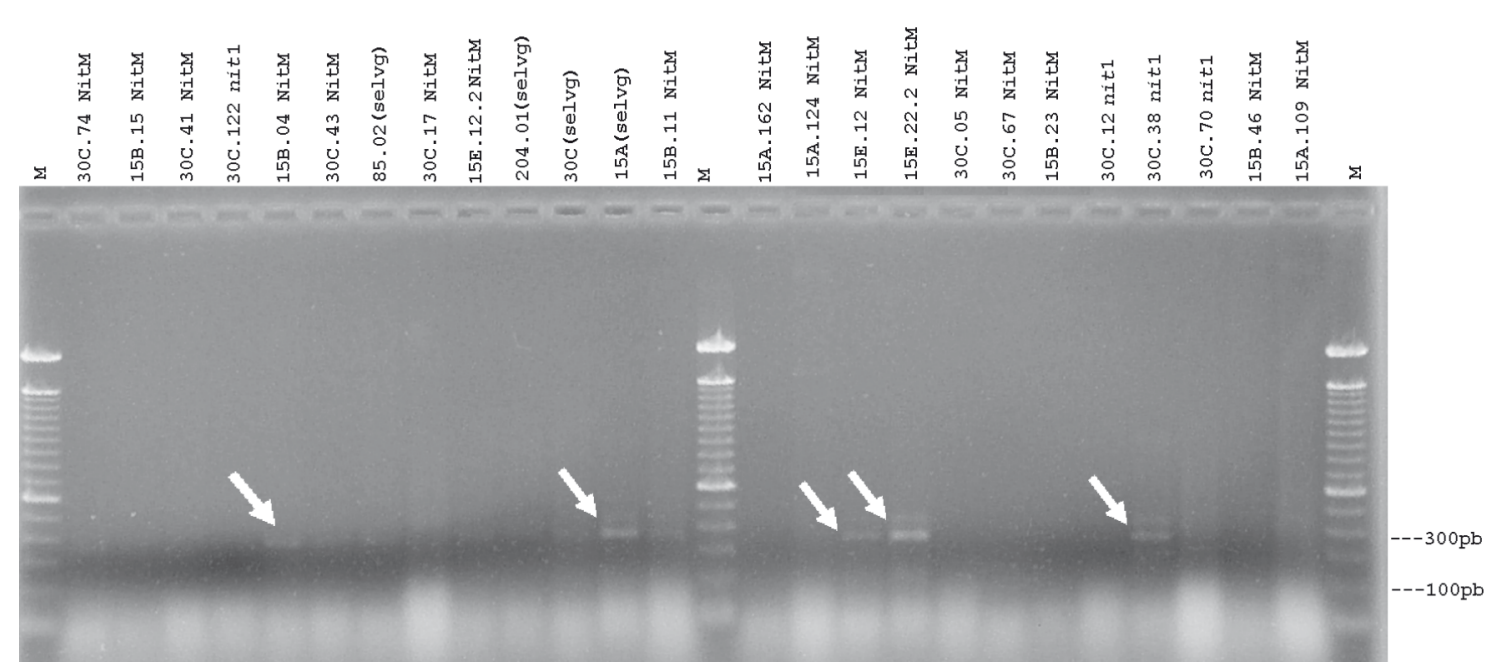

FIGURE 4 - Amplification products of primer SkCM (MAT1) on 1.4\% agarose gel.

the species. There was a high variability in the production of oval and falcate conidia and in the radial growth of the colonies, besides a spontaneous formation of sectors by some strains. These results confirm the high instability of this organism and are in agreement with those described by Souza-Paccola et al. (2003a). Comparing the production of the two types of conidia in each strain, it was observed that the strains 15E.22.2, 15E.15 and 15B.04 did not produced falcate conidia but produced a high number of oval conidia. The strain 30C.151 presented low radial growth and low production of falcate conidia but produced a high number of small oval conidia. The strain 30C.67 also presented a low radial growth, median production of falcate conidia and did not produce oval conidia. It was not possible to correlate mycelial growth with production of one or another conidium type.

\section{Mating-type genes in $C$. sublineolum}

Our results showed that $C$. sublineolum also has a complex mating system. Eleven strains tested presented only the MAT2 idiomorph - similar to the results of Vaillancourt et al. (2000) - 5 strains presented both idiomorph (MAT1 and MAT2) - as the strains of Cochliobolos sp tested by Yun et al. (1999) - and 8 strains did not present either of the two idiomorphs. Two hypotheses can explain the absence of amplification for both idiomorphs on these 8 strains: they do not have the MAT gene or the gene encodes for a MAT protein that does not have a alpha box or HMG box region, similar to the yeast $S$. cerevisiae, where none of the mating-type idiomorphs codes for a protein $H M G$ box (Nelson, 1996).

Some important plant pathogens are classified as anamorphic fungi because their sexual cycle is not known. According to Cover et al. (1999) the molecular 
characterization of mating type allows a significant economy of time and effort in the identification of compatible mating pairs, when attempting to carry out sexual crosses. However, only the mating type characterization may not be enough to obtain sexual reproduction in these organisms, as the ideal environmental conditions to induce mating may be needed. For these asexual fungi, the possibility of identifying the appropriate conditions (mating and environmental), sexual reproduction could be achieved in laboratory. This paper presents new information that can help to achieve successful mating in C. sublineolum, and enable the possibility to expand the genetic analysis of this important plant pathogen.

\section{REFERENCES}

Ali MEK, Warren HL (1987) Physiological races of Colletotrichum graminicola on sorghum. Plant Disease 71:402-404.

Ali MEK, Warren HL (1992) Anthracnose of sorghum. In: Sorghum and millet diseases: a second world review. In: Milliano WAJ, Frederiksen RA, Bengston GD (Eds.) International Crop Research Institute for the Semi-Arid Tropics. Patancheru. India. pp. 203208.

Arie T, Christiansen SK, Yoder OC, Turgeon BG (1997) Efficient cloning of Ascomycetes mating type genes by PCR amplification of the conserved MAT HMG box. Fungal Genetics and Biology 21:118-130.

Bressan W, Figueiredo JEF (2003) Controle biológico de raças e isolados de Colletotrichum graminicola. do sorgo por Actinomicetos. Embrapa milho e Sorgo - Comunicado Técnico, 62 .

Casela CR, Ferreira AS (1995) Virulence associations in the sorghum. anthracnose fungus Colletotrichum graminicola. Fitopatologia Brasileira 20:33-38.

CaselaCR, FerreiraAS(1998)Antracnose do Sorgo(Colletotrichum graminicola). Sete Lagoas MG. Embrapa Milho e Sorgo. Circular Técnica 28. pp. 07-19.

Casela CR, Pinto MFJA, Oliveira E, Ferreira AS (1997) Sorgo (Sorghum bicolor (L.) Moench): controle de doenças. In: Vale FXR, Zambolim L (Eds.) Controle de doenças de plantas. Viçosa MG. Editora UFV. pp. 1025-1064.

Coppin E, Debuchy R, Arnaise S, Picard M (1997) Mating types and sexual development in filamentous ascomycetes. Microbiological Molecular and Biological Reviews 61:411-428.

Covert SF, Briley A, Wallace MM, McKinney VT (1999) Partial MAT-2 gene structure and the influence of temperature on mating success in Gibberella circinata. Fungal Genetics and Biology 28:48-54.

Du M, Schardl CL, Nuckles EM, Vaillancourt LJ (2005) Using mating-type gene sequences for improved phylogenetic resolution of Colletotrichum species complex. Mycologia 97:641-658.

Fávaro LCL, Araújo WL, Souza-Paccola EA, Azevedo JL, Paccola-Meirelles LD (2007) Colletotrichum sublineolum genetic instability assessed by mutants resistant to chlorate. Mycological Research 111:93-105.

Guimarães FB, Casela CR, Santos FG, Pereira JCR, Ferreira AS (1999) Avaliação da resistência de genótipos de sorgo a antracnose. Summa Phytopathologica 25:308-312.

Harris HB, Johnson JB (1967) Sorghum anthracnose symptoms: importance and resistance. Proceedings of the Fifth Biennial Grain Sorghum Research and Utilization Conference. pp. 48-52.

Nelson MA (1996) Mating systems in ascomycetes: a romp in the sac. Trends in Genetics 12:69-74.

Souza-Paccola EA, Fávaro LCL, Bomfeti CA, Mesquita SFP, Paccola-Meirelles LD (2003a) Cultural characterization and conidial dimorphism in Colletotrichum sublineolum. Journal of Phytopathology 151:383-388.

Souza-Paccola EA, Fávaro LCL, Casela CR, Paccola-Meirelles LD (2003b) Genetic recombination in Colletotrichum sublineolum. Journal of Phytopathology 151:329-334.

Turgeon BG (1998) Application of mating type technology to problems in fungal biology. Annual Reviews of Phytopathology 36:115-137.

Turgeon BG, Yoder OC (2000) Proposed nomenclature for mating type genes of filamentous ascomycetes. Fungal Genetics and Biology 31:1-5.

Vaillancourt LJ, Du M, Wang J, Rollins J, Hanau RM (2000) Genetic analysis of cross fertility between two self-sterile strains of Glomerella graminicola. Mycologia 92:430-435.

Wirsel F, Turgeon BG, Yoder OC (1996) Deletion of the Cochliobolus heterostrophus mating-type (MAT) locus promotes the function of MAT transgenes. Currents Genetics 29:241-249.

Yun SH, Berdee ML, Yoder OC, Turgeon BG (1999) Evolution of the fungal self-fertile reproductive life style from self-sterile ancestors. Proceedings National Academy of Science of the USA 96:5592-5597. 